\title{
Geophysical Investigation on the Depth of Saline/Fresh Water in Sandy Islands in Parts of Rivers State, Nigeria \\ ${ }^{1}$ Physics Department, Rivers State University, Nkpolu-Oroworukwo, Rivers State, Nigeria
}

\author{
${ }^{1}$ G. E. Jaja, ${ }^{1}$ O. A. Davies and ${ }^{1}$ V. Baatee \\ DOI: 10.29322/IJSRP.11.08.2021.p11613 \\ http://dx.doi.org/10.29322/IJSRP.11.08.2021.p11613
}

\begin{abstract}
For decades, saline water contamination of fresh drinkable water has been a major problem in many coastal communities in Rivers State. It is suspected that with an increase in population and industrialization, this problem is going to get worse with time. This study was therefore designed to delineate saline/fresh water aquifers in some coastal communities in Rivers State, Nigeria. To this end, Vertical Electrical Sounding (VES), employing the Schlumberger array, was carried out in twelve (12) coastal communities in Rivers State. The total current electrode spread of the sounding varied from $240 \mathrm{~m}-800 \mathrm{~m}$. Data obtained was used to estimate the apparent resistivity of the subsurface rocks, which was plotted on a log graph against half current electrode separation spacing and then analysed to determine depth to subsurface structures and their hydrogeologic characteristic. Results obtained showed that brackish and saline water were mostly present in the study areas at depth range of $5.57 \mathrm{~m}$ to $75 \mathrm{~m}$ while freshwater was present in some study area at an estimated depth of $8 \mathrm{~m}$ below the surface. Therefore, there is an overlap in the depth of freshwater/saline water aquifers within Rivers State.
\end{abstract}

Index Terms- Groundwater, Freshwater, Resistivity, Aquifers, Saline, Rivers State.

\section{INTRODUCTION}

$I^{n}$ nvasion and encroachment of saline water from the oceans into the freshwater aquifers in coastal regions is a well-known phenomenon. A major fall in the water table in coastal aquifers is caused by a rise in groundwater usage in onshore regions $[1,2]$. The hydro-geological gradient should be from the land towards the ocean, in an ideal situation. However, the hydro-geological gradient reverses from the ocean to the ground due to overexploitation and initiates the process of saltwater intrusion $[3,4]$. Continued coastal aquifer exploitation speeds up the infiltration of saline water into freshwater aquifers. Due to uncertainty, freshwater aquifers become dangerous in the presence of saltwater aquifers [5]. To investigate the fresh/saline water aquifers, surface resistivity investigations and data interpretations are carried out. These geophysical data analysis and resolution methods, however, are not always reliable solutions for distinguishing aquifers of freshwater and salty water [6]. The primary causes of the limitations and restrictions of geophysical data interpretation, namely vertical electrical sounding (VES), are similarities in geophysical characters, namely the resistivities of freshwater and saline water aquifers [7].

The most realistic solutions for the implementation of exploration programmes are exploratory drilling and geophysical well logging [8]. However, they are bulky and costly. Therefore, the most used geophysical technique for groundwater exploration is VES, which is low-budget, simple and faster [9]. The vertical electrical sounding technique of electrical resistivity works well and resolves the aquifers of freshwater and salty water in regions away from the coast satisfactorily. The freshwater aquifers are dense in these areas, relative to the saline water aquifers underlying them. There will be an appreciable resistivity comparison between freshwater and saline water aquifers due to the above factors. Hence, the aquifer resolution will be accurate $[6,10]$.

Evidence has also shown that in the sub-surface structural investigation, geophysical methods are reliable and precise techniques [11, 12, 13, 14]

As the earth's media, composing various sub-surface layers, serve as a natural barrier for water penetration, ground water is shielded from surface contaminants. The successful extraction of groundwater in sedimentary terrain requires a proper understanding of its geo-hydrological characteristics $[15,16]$. As saline (salty) water is drawn into a freshwater aquifer, saltwater intrusion happens and it can affect one well or several wells in an aquifer, making the water unpleasant to drink. The saline water/freshwater depth is an unavoidable issue of sandy islandrelated coastal freshwater aquifers [8]. When irrigated with saline groundwater, plant health and soil fertility may be negatively impacted. The changes in the aquifer can be permanent once saltwater intrusion occurs or may take several years to recover $[17,18]$.

Many coastal communities in Rivers State have been experiencing saltwater contamination of water supply wells for many decades $[19,20]$. These problems will likely become worse with increased groundwater abstraction caused by increased population and high industrial activities. Saline/freshwater depth is the movement of saline water into the freshwater aquifers, which can lead to contamination of potable drinking water sources and other consequences [21]. Saline water/freshwater depth is an inevitable problem of coastal freshwater aquifer associated with sandy Island [8]. Saline/freshwater depth exists naturally to some degree in most coastal aquifers, owing to hydraulic relation between groundwater and seawater. It is denser and has higher water pressure because saline water has a 
higher mineral content than freshwater. As a result, freshwater can be pushed inland by saline water [22]. Therefore, there arises a vital need to monitor the feasible risk of saline water/freshwater depth of sand-fill aquifer such as Abonnema, kula and Borokiri sandfill island aquifer because it is extremely difficult to overcome and improve the management of water resource based on long term strategy. The solution to this problem has prompted the researchers in this work to carry out a geophysical investigation of saline/freshwater depth in order to provide information on the geo-section so that groundwater exploration can be protected for future use.

\section{Hydrogeology OF THE StUdy AREA}

The hydrogeology of an area is controlled by factors such as the geology as well as the climate of the region. This is true because the geological formations underlying the area and their structures determine the type of aquifers that would be developed and how they would be recharged, and the climate determines the amount and rate of recharge of the aquifers [23, 24].

The groundwater in the parts of Rivers State is contained in the saturated sandstone unit of the location. Rain is lost as run-off which drains by gravity to the River Niger. Some of it gathers in pools and poodles all over the town/community from where it is evaporated or infiltrates into the ground as direct recharge. The groundwater movement mechanism in the field is related to the geology factor. The amount of rainfall occurring in a basin will decide the water input into the basin [25]. On an average, the amount of rainfall in the Niger Delta is relatively on the high side, ranging from $300 \mathrm{~mm}$ per year in the northern most part of the Delta to $500 \mathrm{~mm}$ per year at the coast $[26,27]$. The sum of water evaporation and transpiration from the surface area of the Delta is about $1000 \mathrm{~mm}$, leaving an effective rainfall of $2000 \mathrm{~mm}$ [26]. About $750 \mathrm{~mm}$, i.e. $35 \%$, of this effective rainfall goes into restoring the subsurface aquifer, while the remaining $1250 \mathrm{~mm}$, i.e. $75 \%$, proceed directly into the streams $[27,28]$. This $75 \%$ is typically on the high side, relative to the range of values that have been commonly reported for unconsolidated sediments [27, 29].

In an effort to enhance the geophysical understanding of coastal aquifers and figure out the ambiguities, a lot of research has been carried out, complicating the interpretation of resistivity data in coastal regions. The Niger-Delta Basin is a major sedimentary basin in Nigeria which has attracted the attention of geologists, geophysicists, hydrogeologists, and other scientists. The study area is characterized by geological structures and zones of economic deposits. Hence, details of the geology of the Niger Delta have been discussed by several authors [30, 31, 32, 33, 34]. All these previous researches have all come to one general consensus; there are three (3) major litho-stratigraphic units in the Niger Delta. These stratigraphic units include the Akata, Agbada and Benin Formations (oldest to youngest).

Due to the depositional pattern as sediments were accumulated during the formation stage of the Delta, the Agbada formation is rift with structural traps (growth faults and anticlines), constituting petroleum containing reservoirs that are tailor-made for petroleum accumulation. These reservoirs are however too deep to be major players in exploring for water [26]. The main body of groundwater in the Niger Delta is contained mainly in very thick and extensive sand and gravel aquifers in the Benin Formation with three distinct zones; a northern bordering zone consisting of shallow aquifers of predominantly continental deposit, a transition zone of intermixing marine and continental materials and a coastal zone of predominantly marine deposits $[35,36,37]$.

\section{METHOD AND MATERIALS}

Twelve (12) Vertical Electrical Sounding data which were from saltwater swamp and coastal beached/ridges were used for this study. The equipment used for the vertical electrical sounding consist of ABEM Terrameter SAS 300B, four pair of Electrode, measuring tapes, brass hammer, four reels of cables, four interconnected wires, 12 volts battery, field data sheet and Global positioning system for taking the coordinates of the survey site.

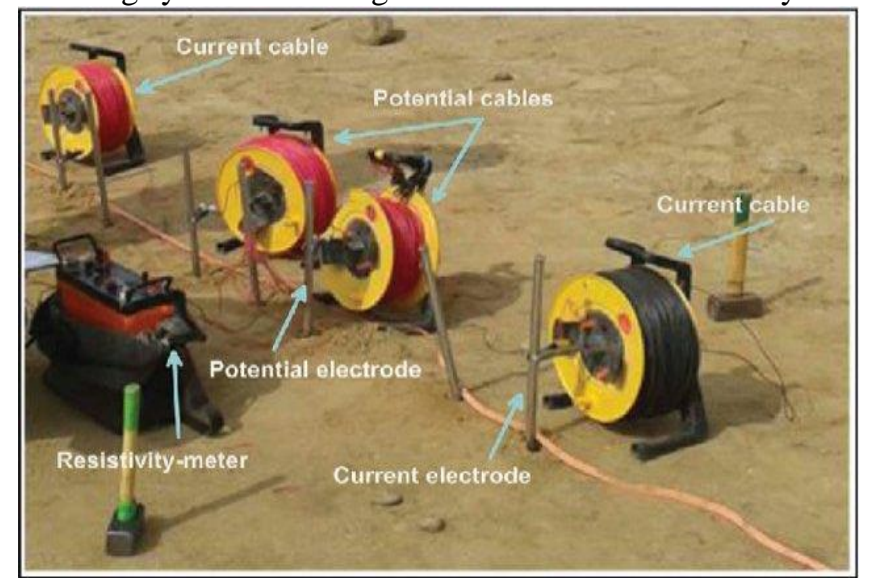

Figure 1: ABEM Terrameter 300B with accessories necessary for filed measurements [38]

The technique employed in this study is the Schlumberger method. This is carried out with a resistance meter that gives the value of ground resistance $\mathrm{R}$ directly; the four electrodes inline but not at the same distance is push into the ground to a depth about $0.4 \mathrm{~m}$ in such a way as to guarantee close electrical contact with the ground.

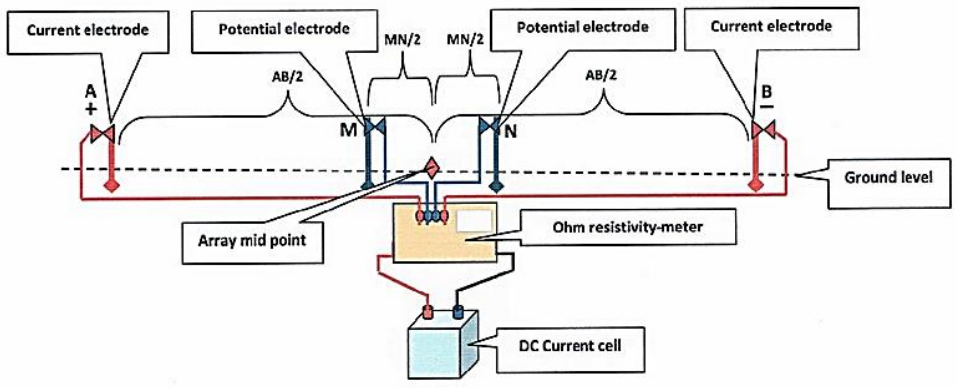

Figure 2: The electrode array for Schlumberger configuration at field resistivity survey [39].

The value of the apparent resistivity, $\rho$ was estimated by the mathematical relationship according to Reynolds [40];

$$
\begin{gathered}
\rho=\left(\frac{\Delta V}{I}\right) K \\
K=\pi\left(\frac{(A B)^{2}-(M N)^{2}}{M N}\right)
\end{gathered}
$$


Where,

$K=$ Geoelectric Factor

$A M=$ Current electrode spacing

$M N=$ Potential electrode spacing

The Names and Coordinates of the study areas in this work are shown in Table 1.

Table 1: Location and Coordinates of Study Areas

\begin{tabular}{|l|c|c|}
\hline \multirow{2}{*}{\multicolumn{1}{|c|}{ VES Location }} & \multicolumn{2}{c|}{ Coordinate } \\
\cline { 2 - 3 } & Northing & Easting \\
\hline Ibiebele-Ama & 522483 & 298561 \\
\hline Olokuma & 497406 & 326937 \\
\hline NLNG & 530307 & 280446 \\
\hline Ikuru & 493989 & 330909 \\
\hline Opobo & 498779 & 338133 \\
\hline Borokiri-Sandfill & 530919 & 281176 \\
\hline Abonnema & 534839 & 281944 \\
\hline Omekwe-Tari Ama & 528199 & 259112 \\
\hline Kula & 479604 & 238747 \\
\hline Bille & 506515 & 265577 \\
\hline Oyorokoto & 491906 & 314922 \\
\hline Ekwe-ama & 524173 & 259487 \\
\hline
\end{tabular}

\section{A. Field Procedure}

The immediate aim of geo-electric prospecting is to institute the electrical resistivity distributions of the subsurface rock formation from which subsurface depth and structures in the area of interest can be deduced. In this work, direct current was passed into the ground from the ABEM Terrameter signal averaging system 300B by means of a pair of current electrodes and the resulting potential difference is measured between two properly placed electrodes with respect to the current electrodes. A typical layout of the field procedure is shown in Figure 2. A and $\mathrm{B}$ represent the positive and negative electrode through which the current is injected into the ground (earth) while $\mathrm{M}$ and $\mathrm{N}$ represent the electrode pair across which the potential difference caused by the injected current is measured; $\mathrm{O}$ indicates the centre of the configuration sounding points. The procedure is expanding electrodes $\mathrm{A}$ and $\mathrm{B}$ in a symmetrical distance from centre $\mathrm{O}$, while $\mathrm{MN}$ was kept fixed. For each reading, the current passed into the ground via $A B$ generated a potential difference between $\mathrm{M}$ and $\mathrm{N}$. When the magnitude of the current electrode is increased; MN was then increased to have a measurable potential. The resistance values were recorded on the field data sheet.

\section{B. Field Data Interpretation}

The result of the VES was interpreted using the IPI2win software to identify the saline / freshwater zone while the well log data was interpreted on a graph of Microsoft excel in other to generate the lithologic section. The apparent resistivity obtained from equation 1 was plotted on a log graph against half current electrode separation spacing. From the plot, quantitative deductions such as the resistivity of the top layers, the depth of each layer and the curve signatures or type were made. The initial quantitative interpretation was made using partial curve matching technique in which the field curves produced were matched segment by segment with the appropriate master curves and auxiliary curves. The resistivities and thicknesses of the various layers were improved upon by employing an automated iteration computer program following the ideas of Zohdy et. al. [41]. The IPI2win computer Software was employed for carrying out the iteration and inversion process. Each iteration and inversion processes were conducted for each sounding station until the RMS error of less than 5\% was obtained.

\section{RESUlT AND DISCUSSION}

\section{A. VES Implications of Ibiebele-Ama}

Geophysical survey curve and Model for Ibiebele-Ama in Ogu/Gbolo local Government area of Rivers State is shown in Figure 3. From the curve, a four geo-electric layer rock is seen with AA-curve type dominant. The curve shows a gradual increase in resistivity values from $0.831 \Omega \mathrm{m}$ to $87.6 \Omega \mathrm{m}$. The first and second layer shows resistivity values from $0.831 \Omega \mathrm{m}$ to $5.64 \Omega \mathrm{m}$ which could be indicative of that only brackish/saline water column was captured at this depth with peat and saturated sandy-clay formation according to Jansen [42]. The second and the third layers contain clay and fine sand mixture as they have relatively low formation resistivity value of $30 \Omega \mathrm{m}$ and $87.6 \Omega \mathrm{m}$ respectively [42]. The non- availability of space led to a total current electrode spread of $240 \mathrm{~m}$ probing only the depth $36 \mathrm{~m}$ hence, the survey could not capture the freshwater/ saline water composition despite that it was done on a Sandy Island.

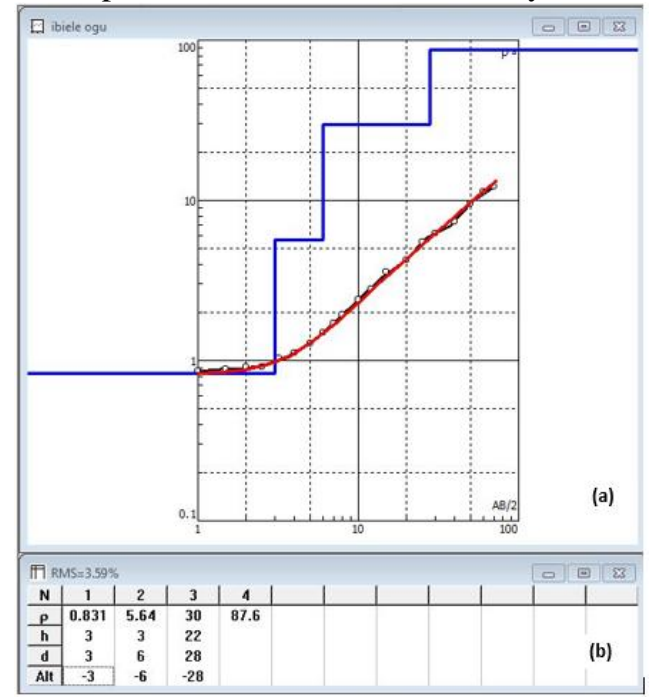

Figure 3: VES Curve (a) and Model (b) for Ibiebele-Ama

\section{B. VES Implications of Olokuma}

Figure 4 reveals the vertical electrical sounding curve of Sandfilled Olokuma in Andoni Local Government Area of Rivers State. The curve possesses a 3-layer formation with array of formation resistivity value of $1.51 \Omega \mathrm{m}$ to $3786 \Omega \mathrm{m}$. The survey is characterized by A-curve type. The investigated area is also characterized lithologically by sand with thin clay layer, which 
is typical of coastal beaches and ridges geomorphic environment. Irrespective of the growing curve, the first two layers contains pure saline/brackish water owing to their low apparent resistivity. Layer three of the formation with depth greater than $10 \mathrm{~m}$ contains relatively freshwater as a result of the comparatively higher formation resistivity values.

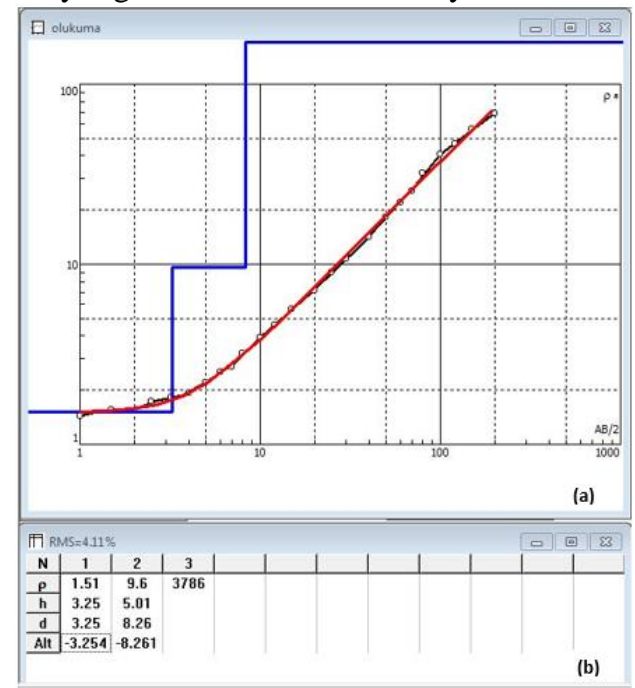

Figure 4: VES Curve (a) and Model (b) for Olokuma

\section{VES Implications of NLNG}

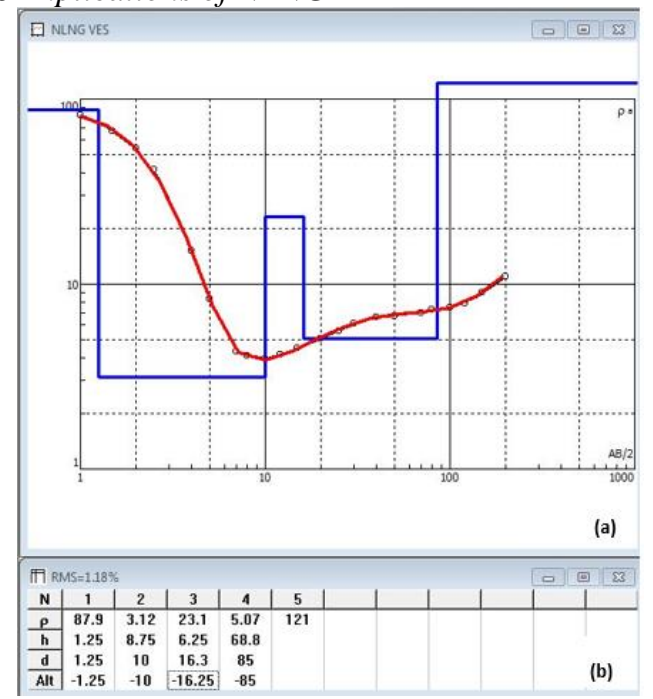

Figure 5: VES Curve (a) and Model (b) for NLNG

Figure 5 indicates the geophysical survey of NLNG new site in Port Harcourt Local Government Area of Rivers State. From the survey, a total spread of $400 \mathrm{~m}$ electrode spacing was carried in course of the survey the probe depth of $100 \mathrm{~m}$ which result shows that five geo-electric layers were encountered. The curve shows a typical HKH-curve type with varying resistivity values of $3.12 \Omega \mathrm{m}$ to $121 \Omega \mathrm{m}$. The top layer is made up of fine-sand having a resistivity value of $87.9 \Omega \mathrm{m}$. This layer contains top sand formation to depth of $1.25 \mathrm{~m}$. The second layer with a drop in resistivity value to $3.12 \Omega \mathrm{m}$ indicate a saturated clay formation which contain saline/brackish water with Total Dissolve Solid (TDS) [41]. It is seen that the high conductive nature of the saline water makes the resistivity curve to drop drastically as seen in the figure. The third layer with a little rise in the resistivity to $23.1 \Omega \mathrm{m}$ indicates a sandy clay formation that contains high TDS water but in saline water according to Hasan et. al. [43]. This occurs between depths of $10 \mathrm{~m}$ to $16.3 \mathrm{~m}$. The fourth layer with layer with a drop in resistivity value of $5.07 \Omega \mathrm{m}$ represent a saturated clay/sand formation with salty/ brackish water. However, fresh water starts from depth of 90$100 \mathrm{~m}$ with an indication of rise in the resistivity value of $121 \Omega \mathrm{m}$.

\section{VES Implications of Ikuru}

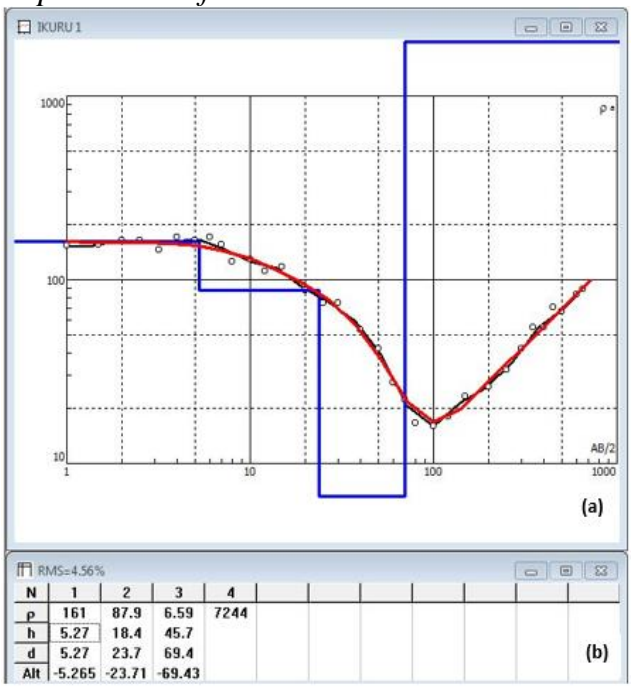

Figure 6: VES Curve (a) and Model (b) for Ikuru

Figure 6 depicts the vertical electrical sounding curve for Ikuru town in Andoni Local Government Area, Rivers State, Nigeria. The curve shows an QH-characteristics type of curve. However, four geologic sections are seen with formation of sand for the first layer to coarse sand for the fourth layer which is a typical of a coastal beach geomorphologic unit of the Niger Delta [44]. The survey has varying resistivity value between $6.59 \Omega \mathrm{m}$ to $7244 \Omega \mathrm{m}$. Layer one and two contains relatively fresh water but contaminated with likely TDS while layer three with low apparent resistivity value of $6.59 \Omega \mathrm{m}$ is made up of silt/clay formation with brackish water at depth of $69.4 \mathrm{~m}$ [41]. Nevertheless, saline water formation was not captured in this survey.

\section{E. VES Implications of Opobo}

Figure 7 represent the VES Curve for Opobo Town in Opobo/Nkoro Local Government Area, Rivers State, Nigeria. A view of the curve shows that five subsurface layers are encountered with HKH curve type. The area has varying resistivity values of $6.260 \Omega \mathrm{m}$ to $348.3 \Omega \mathrm{m}$ with thickness range of $5 \mathrm{~m}$ to $25 \mathrm{~m}$. The topmost layer has resistivity value of $63.52 \Omega \mathrm{m}$ indicating top humid soil with thickness of about $5 \mathrm{~m}$. The second layer with resistivity value of $20.52 \Omega \mathrm{m}$ is made up of brackish water with saturated clay acts like a protective coverage to third layer which a resistivity value of $126.9 \Omega \mathrm{m}$ has believed to contain fresh water with high TDS base on the resistivity value encountered in the layer. The fourth layer with resistivity value of $6.260 \Omega \mathrm{m}$ could be indicative of saturated sandy formation 
containing saline water mixed with high TDS [43]. This occurred at depth of $75 \mathrm{~m}$. The fifth layer with resistivity value of $348.3 \Omega \mathrm{m}$ contain the freshwater zone of the area which fresh water can be taped for human consumption. Although the depth and the thickness of the layer are infinite, however, this occurs at depth greater than $75 \mathrm{~m}$.

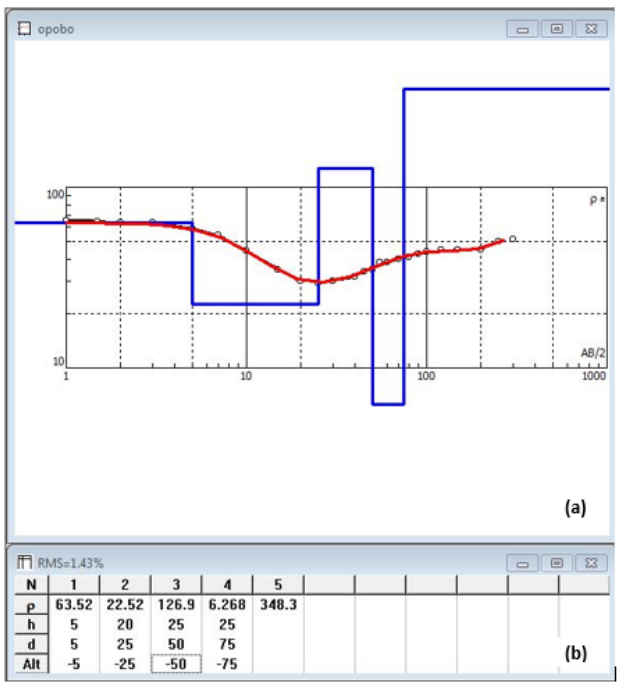

Figure 7: VES Curve (a) and Model (b) for Opobo

\section{F. VES Implications of Borokiri-Sandfill}

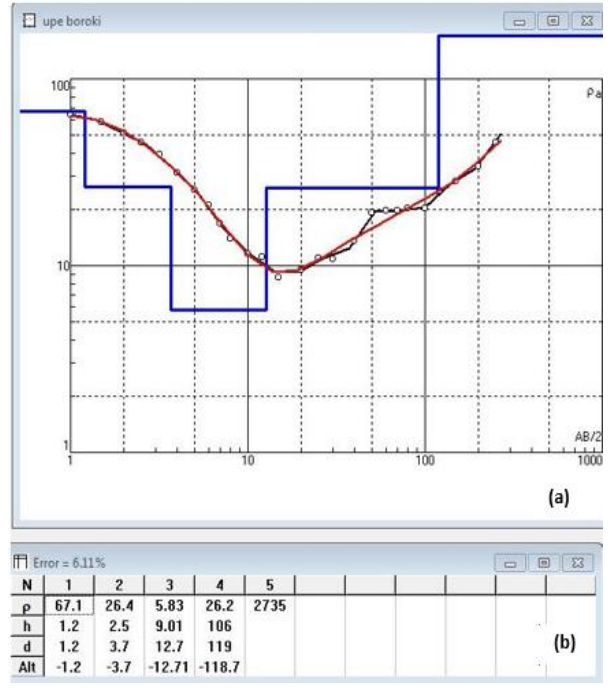

Figure 8: VES Curve (a) and Model (b) for Borokiri-Sandfill

Borokiri-Sandfill (in Port Harcourt Local Government Are, Rivers State, Nigeria) Vertical Electrical Sounding result is displayed in Figure 8. In the study area, a total spread of $500 \mathrm{~m}$ was taken for maximum current electrode spacing. It is observed that there are five-layer geologic successions with range of subsurface resistivity between $5.83 \Omega \mathrm{m}$ to $2735 \Omega \mathrm{m}$ with thickness range of $1.2 \mathrm{~m}$ to $106 \mathrm{~m}$ with QHK- curve type. From the figure, the near surface layer with thickness of $1.2 \mathrm{~m}$ and resistivity of $67.1 \Omega \mathrm{m}$ consists of sand/clay composition. This zone does not contain saline/fresh water; however, it is a transition zone with occurrence of brackish water. Layer 2 and layer 3 with resistivity values of $26.4 \Omega \mathrm{m}$ and $5.83 \Omega \mathrm{m}$ are predominately saline water zone with layer dominated by claysand formation. This Layer freshwater contain sand formation with moderately freshwater while the fifth layer is made up of coarse sand with saturated freshwater.

\section{G. VES Implications of Abonnema Town}

The Vertical Electrical sounding result of Abonnema town in Akuku-Toru Local Government Area, Rivers State, Nigeria, is shown in Figure 9. From the figure, four geologic layer formations are seen with varying apparent resistivity of $1.17 \Omega \mathrm{m}$ to $374 \Omega \mathrm{m}$ with $\mathrm{AH}$ - curve type. The first Geologic layer with resistivity value of $23.1 \Omega \mathrm{m}$ consists of topsoil with formation thickness of $0.741 \mathrm{~m}$. The second layer comprise sand-clay formation with resistivity value of $13.3 \Omega \mathrm{m}$ has brackish/saline water occurrence. The third layer of the curve which is characterized with $4.37 \mathrm{~m}$ thickness and resistivity value of $1.17 \Omega \mathrm{m}$ is made up of clay formation with saline water presence. however, from the fourth layer with increased resistivity value of $374 \Omega \mathrm{m}$ contains medium to coarse sand is an indicative of freshwater occurrence which starts at $8 \mathrm{~m}$ to the final probe depth of $100 \mathrm{~m}$.

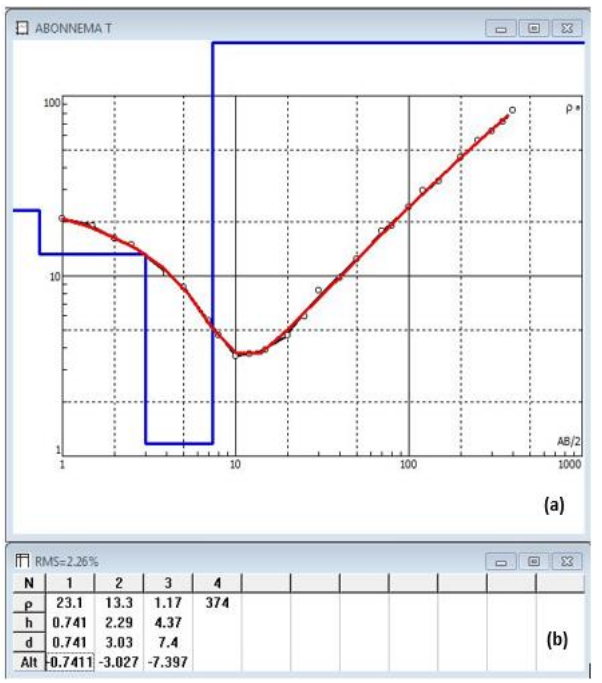

Figure 9: VES Curve (a) and Model (b) for Abonnema Town

\section{H. VES Implications of Omekwe-Tari Ama}

The Vertical Electrical Sounding curve for Omekwe-Tari-Ama in Asari-Toru Local Government Area, Rivers State, Nigeria, is displayed in figure 10. The figure depicts a four-layer formation with HK-curve type with subsurface resistivity range of $2.83 \Omega \mathrm{m}$ to $560 \Omega \mathrm{m}$ with varying substratum thickness of $1 \mathrm{~m}$ to $50 \mathrm{~m}$. The first layer represents a top consolidated soil with resistivity value of $560 \Omega \mathrm{m}$. considering the local geology of the area, the second layer which runs from the depth of $1 \mathrm{~m}$ to $25 \mathrm{~m}$ contains porous sandy-clay formation with saline water with resistivity value of $2.83 \Omega \mathrm{m}$. Beneath this layer is the third layer with resistivity value of $20.5 \Omega \mathrm{m}$. This layer is made up of a thick clay formation which acts like a protective capacity to the underlying layer. The last layer with resistivity value of $349 \Omega \mathrm{m}$ is made up of coarse sand formation with occurrence of fresh water. 


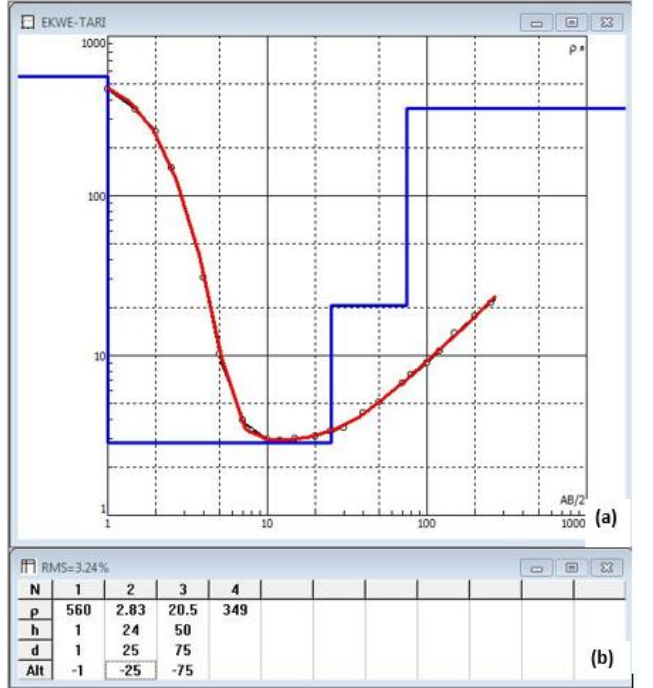

Figure 10: VES Curve (a) and Model (b) for Omekwe-Tari Ama

\section{VES Implications of Kula}

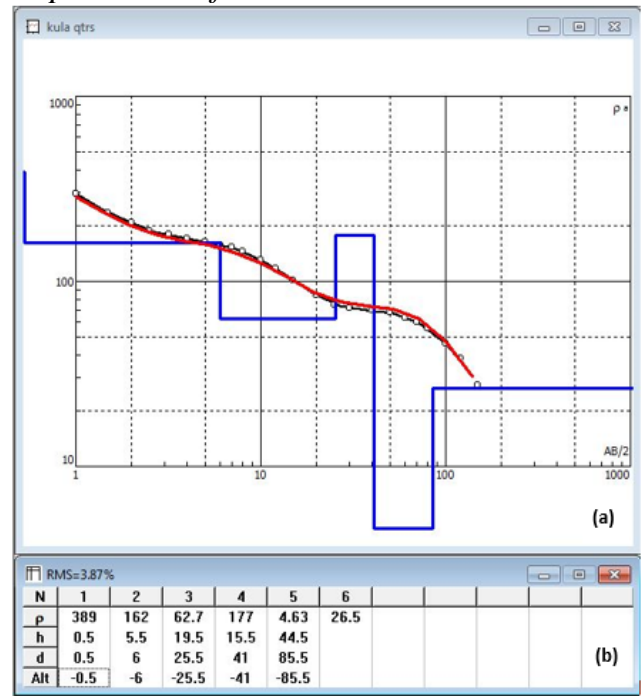

Figure 11: VES Curve (a) and Model (b) for Kula

Figure 11 represent the Geophysical sounding curve of Kula town in Akuku-Toru Local Government area of Rivers State located along the Geomorphologic coastal beaches/ridges. The curve confirms a four-layer resistivity formation with characteristics of QHKH-curve type and with altering formation resistivity value between $0.307 \Omega \mathrm{m}$ to $758 \Omega \mathrm{m}$ respectively. The curve shows a decreasing resistivity from the top of the formation to the bottom indicating a high conductivity fluid. The first layer is made up of top consolidated sandy soil with resistivity value of $758 \Omega \mathrm{m}$ with $0.646 \mathrm{~m}$ thick. The second layer and the third layer with resistivity values of $164 \Omega \mathrm{m}$ and $129 \Omega \mathrm{m}$ made up of fine to medium sand with presence of fresh water. In view of the local geology of the area, the forth layer with low resistivity value of $0.307 \Omega \mathrm{m}$ is an indicative of saline water presence according to Zohdy et. al. [41].

\section{J. VES Implications of Bille}

Figure 12 shows the VES curve of Bille Town in Degema Local Government Are of Rivers State, Nigeria. From the curve, five
Geo-electric layers are seen with changing resistivity value of $0.0066 \Omega \mathrm{m}$ to $0.0264 \Omega \mathrm{m}$ and with QHK -curve type. The low resistivity value seen indicates resistivity values typical of saltwater swamp and coastal beaches formation [45]. It is evident from the survey that from the top formation to the depth of penetration, there is no freshwater presence. This is due to very low apparent resistivity value seen in the formation. More so, it is also noted that the survey covers only a maximum electrode spread of $240 \mathrm{~m}$ probing the depth of $60 \mathrm{~m}$ and could not capture freshwater zone, hence the survey probe depth only contains saline water without the presence of fresh water.

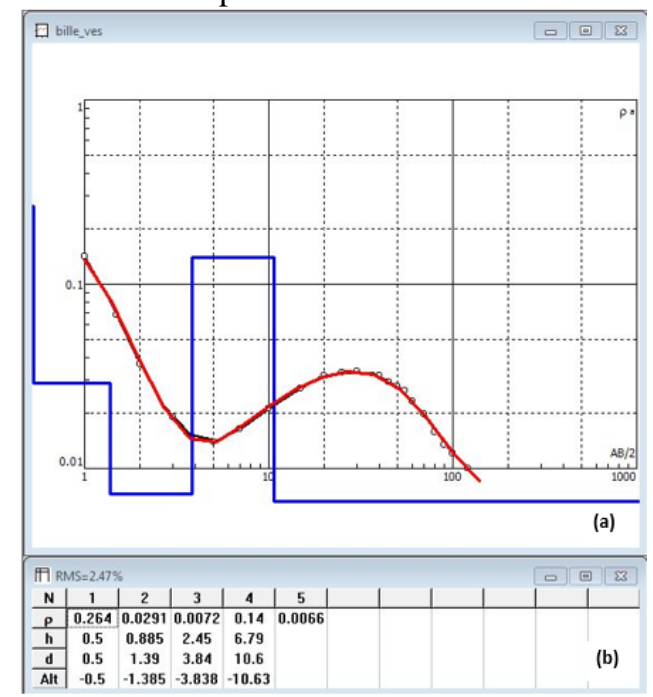

Figure 12: VES Curve (a) and Model (b) for Bille

K. VES Implications of Oyorokoto

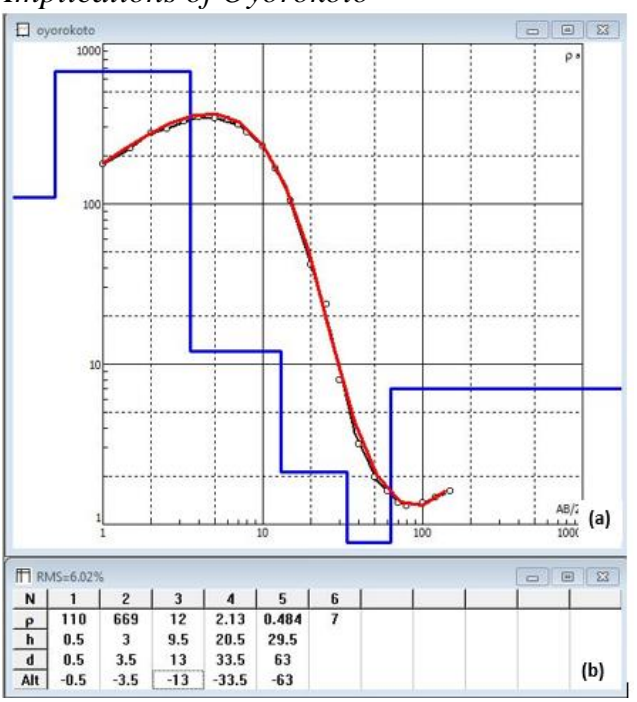

Figure 13: VES Curve (a) and Model (b) for Oyorokoto

Figure 13 shows the Vertical Electrical Sounding model and curve result of Oyorokoto in Andoni local Government area of Rivers State, Nigeria. The survey shows a total current electrode spacing of $300 \mathrm{~m}$. From the figure, a six-layer formation is seen with apparent resistivity range of $0.484 \Omega \mathrm{m}$ to $669 \Omega \mathrm{m}$ with KAH curve-type. The first layer is characterized by sandy formation with high resistivity value of $110 \Omega \mathrm{m}$ with thickness of $0.5 \mathrm{~m}$. The second layer has a resistivity value of $669 \Omega \mathrm{m}$ with 
a formation thickness of $3 \mathrm{~m}$ at depth of $3.5 \mathrm{~m}$. It is important to note that layer 2 of the survey possess intermediate contaminated fresh water due to the high formation resistivity value. The third layer with formation resistivity value of $12 \Omega \mathrm{m}$ reveals the presence of saturated clay formation at a depth of $13 \mathrm{~m}$. The fourth layer with formation resistivity of $0.484 \Omega \mathrm{m}$ which occur at a depth of $33.5 \mathrm{~m}$ with $20.5 \mathrm{~m}$ thick indicate the presence of saline water. Based on the geology of the area, this layer formation is made up of sand- clay [41]. The last layer with resistivity value of $7 \Omega \mathrm{m}$ comprises saturated clay formation but possess no aquifer parameters.

\section{VES Implications of Ekwe-Ama}

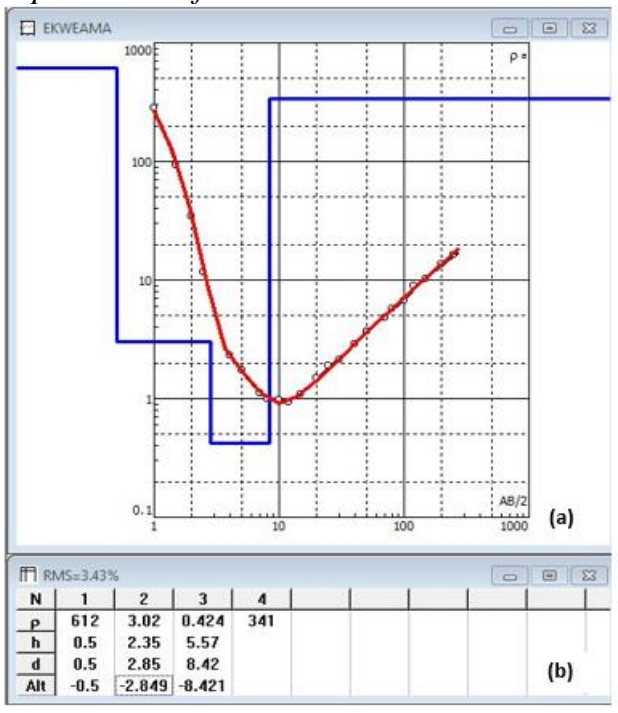

Figure 14: VES Curve (a) and Model (b) for Ekwe-Ama

Figure 14 depicts the Vertical Electrical sounding curve result for Ekwe-Ama in Degema Local Government Area in Rivers State, Nigeria. The survey shows a characteristic of HA- curve type with a four-layer formation. The layers have varying resistivity value between $0.424 \Omega \mathrm{m}$ to $612 \Omega \mathrm{m}$ with thickness range of $0.5 \mathrm{~m}$ to $5.57 \mathrm{~m}$. The first layer shows a top sandy formation with resistivity values of $612 \Omega \mathrm{m}$. The second layer shows a sandyclay formation with a drastic fall of the apparent resistivity to $3.02 \Omega \mathrm{m}$. Taking the geology of the area into account, the layer is filled up with brackish water that is highly contaminated. The third layer which is the last layer encountered during the survey with resistivity of $0.424 \Omega \mathrm{m}$ and thickness of $5.57 \mathrm{~m}$ is saturated with saline water with dominant of clay formation. The last layer with resistivity of $341 \Omega \mathrm{m}$ is made up of coarse sand that contains fresh water.

\section{CONCLUSION}

The study was aimed at delineating saline/freshwater structure in coastal sandfill Island in parts of Rivers State, Nigeria, from estimates of apparent resistivity of the in-situ rock as determined from 1D vertical electrical sounding (VES), employing the Schlumberger array. The VES survey was carried out in twelve (12) locations within the state, including sites at Port Harcourt, Asari-Toru, Akuku-Toru, Degema, Andoni and Opobo/Nkoro Local Government Areas. The data obtained apparent resistivity obtained was plotted on a log graph against half current electrode separation spacing. The following conclusions were arrived at from the obtained results.

i. There were a three-to-five-layer subsurface structures in the study areas, composed mainly of sand and clay intercalations.

ii. The resistivity curve types observed in the study area included Ibiebele-Ama - AA, Olokuma - A, NLNG HKH, Ikuru - QH, Opobo - HKH, Borokiri-Sandfill QHK, Abonnema - AH, Omekwe-Tari Ama - HK, Kula QHKH, Bille - QHK, Ekwe-Ama - HA, Oyorokoto KAH.

iii. Brackish and Saline water were mostly present in the study areas at depth range of $5.57 \mathrm{~m}$ to $75 \mathrm{~m}$.

iv. Freshwater was present in some study area at an estimated depth of $8 \mathrm{~m}$ below the surface to the final probe depth of $100 \mathrm{~m}$.

v. There is thus an overlap in the depth of freshwater/saline water aquifers within Rivers State.

vi. Determination of freshwater/saline aquifer depth should therefore be site specific.

\section{ACKNOWLEDGMENT}

The authors will be eternal grateful to Prof. T. K. S. Abam and Dr. B. U. Amechi for all their insights throughout the period this research work lasted.

\section{REFERENCES}

[1] Barlow, P.M., Ground water in freshwater-saltwater environ[ments of the Atlantic coast. Vol. 1262. 2003: Geological Survey (USGS).

[2] Wilson, A.M., Fresh and saline groundwater discharge to the ocean: A regional perspective. Water Resources Research, 2005. 41(2).

[3] Hussain, M.S. and A.A. Javadi, Assessing impacts of sea level rise on seawater intrusion in a coastal aquifer with sloped shoreline boundary. Journal of Hydro-Environment Research, 2016. 11: p. 29-41.

[4] Dhiman, S. and D. Thambi, Ground water management in coastal areas. Bhu-Jal, 2009. 24: p. 69-73.

[5] Sappa, G., S. Ergul, F. Ferranti, L.N. Sweya, and G. Luciani, Effects of seasonal change and seawater intrusion on water quality for drinking and irrigation purposes, in coastal aquifers of Dar es Salaam, Tanzania. Journal of African Earth Sciences, 2015. 105: p. 64-84.

[6] Hodlur, G., R. Dhakate, T. Sirisha, and D. Panaskar, Resolution of freshwater and saline water aquifers by composite geophysical data analysis methods. Hydrological Sciences Journal-Journal des Sciences Hydrologiques, 2010. 55(3): p. 414-434.

[7] Singh, K., Nonlinear estimation of aquifer parameters from surficial resistivity measurements. Hydrology Earth System Sciences Discussion, 2005. 2(3): p. 917-938.

[8] Hwang, S., J. Shin, I. Park, and S. Lee, Assessment of seawater intrusion using geophysical well logging and electrical soundings in a coastal aquifer, Youngkwang-gun, Korea. Exploration Geophysics, 2004. 35(1): p. 99-104.

[9] Shishaye, H.A. and S. Abdi, Groundwater exploration for water well site locations using geophysical survey methods. Hydorlogy Current Research, 2016. 7(1): p. 226.

[10] Samouëlian, A., I. Cousin, A. Tabbagh, A. Bruand, and G. Richard, Electrical resistivity survey in soil science: a review. Soil and Tillage research, 2005. 83(2): p. 173-193.

[11] Ahmed, S., T. Arora, S. Sarah, F.A. Dar, T. Kumar, T.W. Gaur, and P. Raghuvendar, Viewing sub-surface for an effective managed aquifer recharge from a geophysical perspective. Natural Water Treatment Systems for Safe Sustainable Water Supply in the Indian Context: Saph Pani, 2016: p. 301. 
[12] Chalikakis, K., V. Plagnes, R. Guerin, R. Valois, and F.P. Bosch, Contribution of geophysical methods to karst-system exploration: an overview. Hydrogeology Journal, 2011. 19(6): p. 1169-1180.

[13] Kneisel, C., C. Hauck, R. Fortier, and B. Moorman, Advances in geophysical methods for permafrost investigations. Permafrost Periglacial Processes, 2008. 19(2): p. 157-178.

[14] Larson, D.O., C.P. Lipo, and E. Ambos, Application of advanced geophysical methods and engineering principles in an emerging scientific archaeology. First Break, 2003. 21: p. 51-62.

[15] Engelen, G.B. and F.H. Kloosterman, Hydrological systems analysis: methods and applications. Vol. 20. 2012: Springer Science \& Business Media.

[16] Pham, B.T., A. Jaafari, I. Prakash, S.K. Singh, N.K. Quoc, and D.T. Bui, Hybrid computational intelligence models for groundwater potential mapping. Catena, 2019. 182: p. 104101.

[17] Klassen, J. and D. Allen, Assessing the risk of saltwater intrusion in coastal aquifers. Journal of Hydrology, 2017. 551: p. 730-745.

[18] Rasmussen, P., T. Sonnenborg, G. Goncear, and K. Hinsby, Assessing impacts of climate change, sea level rise, and drainage canals on saltwater intrusion to coastal aquifer. Hydrology Earth System Sciences, 2013. 17(1): p. 421-443.

[19] Cookey, P., B.A. Kokpan, A.M. Richard, W. Weridongha, and J.P. Chukwuemeka, Access to sanitation and safe water - Global partnerships and local actions: Proceedings of the 33rd WEDC International Conference, Accra, Ghana, 7-11 April 2008. 2008: p. 383-388.

[20] Tanee, F. and E. Albert, Heavy metals contamination of roadside soils and plants along three major roads in Eleme, Rivers State of Nigeria. Journal of Biological Sciences, 2013. 13(4): p. 264-270.

[21] Adeoti, L., O. Alile, and O. Uchegbulam, Geophysical investigation of saline water intrusion into freshwater aquifers: A case study of Oniru, Lagos State. Scientific Research and Essays, 2010. 5(3): p. 248-259.

[22] Lassiter, A., Rising seas, changing salt lines, and drinking water salinization. Current Opinion in Environmental Sustainability, 2021. 50: p. 208-214.

[23] Vashisht, A. and H. Sharma, Study on hydrological behaviour of a natural spring. Current Science, 2007. 93(6): p. 837-840.

[24] Singhal, B.B.S. and R.P. Gupta, Applied hydrogeology of fractured rocks. 2010: Springer Science \& Business Media.

[25] Archer, D., Contrasting hydrological regimes in the upper Indus Basin. Journal of Hydrology, 2003. 274(1-4): p. 198-210.

[26] Nwankwoala, H. and S. Ngah, Groundwater resources of the Niger Delta: Quality implications and management considerations. International Journal of Water Resources and Environmental Engineering, 2014. 6(5): p. 155-163.

[27] Nwankwoala, H. and G. Udom, A preliminary review of potential groundwater resources of the Niger Delta. International Journal of Applied Environmental Sciences, 2011. 6(1): p. 57-71.

[28] Ophori, D.U., A simulation of large-scale groundwater flow in the Niger Delta, Nigeria. Environmental Geosciences, 2007. 14(4): p. 181-195.

[29] Schultz, G. and C. Ruppel, Constraints on hydraulic parameters and implications for groundwater flux across the upland-estuary interface. Journal of Hydrology, 2002. 260(1-4): p. 255-269.

[30] Short, K. and A. Stauble, Outline of geology of Niger Delta. AAPG bulletin, 1967. 51(5): p. 761-779.

[31] Okeke, O., C. Abiahu, F. Anifowose, and V. Fagorite, A review of the geology and mineral resources of Dahomey Basin, Southwestern Nigeria. International Journal of Environmental Sciences \& Natural Resources, 2019. 21(1): p. 1-5.
[32] Lawrence, S.R., S. Munday, and R. Bray, Regional geology and geophysics of the eastern Gulf of Guinea (Niger Delta to Rio Muni). The leading edge, 2002. 21(11): p. 1112-1117.

[33] Amadi, A., P. Olasehinde, J. Yisa, E. Okosun, H. Nwankwoala, and Y. Alkali, Geostatistical assessment of groundwater quality from coastal aquifers of Eastern Niger Delta, Nigeria. Geosciences, 2012. 2(3): p. 5159.

[34] Reijers, T., S. Petters, and C. Nwajide, The Niger delta basin, in Sedimentary basins of the world. 1997, Elsevier. p. 151-172.

[35] Etu-Efeotor, J. and M. Odigi, Water supply problems in the eastern Niger Delta. Journal of Mining Science and Geology, 1983. 20(1-2): p. 183-193.

[36] Amajor, L., Geological appraisal of groundwater exploitation in the Eastern Niger Delta. Groundwater and Mineral Resources of Nigeria, 1989: p. 85-100.

[37] Etu-Efeotor, J. and E. Akpokodje, Aquifer systems of the Niger Delta. Journal of Mining and Geology, 1990. 26(2): p. 279-284.

[38] Gemail, K., S. Shebl, M. Attwa, S.A. Soliman, A. Azab, and M. Farag, Geotechnical assessment of fractured limestone bedrock using DC resistivity method: a case study at New Minia City, Egypt. NRIAG Journal of Astronomy and Geophysics, 2020. 9(1): p. 272-279.

[39] Alridha, N.A., A.I. Al-Yasi, and W.M.S. AL-Khafaji, The Role of (Geoelectric and Hydrogeologic) Parameters in the Evaluation of Groundwater reservoir at South of Jabal Sinjar area. Iraqi Journal of Science, 2013. 54(3): p. 628-637.

[40] Reynolds, J.M., An introduction to applied and environmental geophysics. 2011: John Wiley \& Sons.

[41] Zohdy, A.A., P. Martin, and R.J. Bisdorf, A study of seawater intrusion using direct-current soundings in the southeastern part of the Oxnard Plain, California. Vol. 93. 1993: US Geological Survey.

[42] Jansen, J.R. Geophysical methods to map brackish and saline water in aquifers. 2011. Georgia Institute of Technology.

[43] Hasan, M., Y. Shang, G. Akhter, and W. Jin, Delineation of saline-water intrusion using surface geoelectrical method in Jahanian area, Pakistan. Water, 2018. 10(11): p. 1548

[44] Jacobberger, P.A., Geomorphology of the upper inland Niger delta. Journal of Arid Environments, 1987. 13: p. 95-112.

[45] Manheim, F.T., D.E. Krantz, and J.F. Bratton, Studying ground water under Delmarva coastal bays using electrical resistivity. Groundwater, 2004. 42(7): p. 1052-1068

\section{AUTHORS}

First Author - Gerald Emmanuel Jaja, MSc Applied Geophysics (In View), Rivers State University, Port Harcourt, Rivers State, Nigeria.

Second Author - Onengiyeofori Anthony Davies, PhD Applied Geophysics, Rivers State University, Port Harcourt, Rivers State, Nigeria.

Third Author - Vurasi Baatee, MSc Applied Geophysics, Rivers State University, Port Harcourt, Rivers State, Nigeria.

Correspondence Author - Onengiyeofori Anthony Davies, davies.onengiyeofori@ust.edu.ng 